\title{
PERAN LEMBAGA KEUANGAN SYARIAH PENERIMA WAKAF UANG (LKS-PWU) BAGI OPTIMALISASI WAKAF UANG
}

\author{
Qurratul `Aini Wara Hastuti \\ Panitera Pengadilan Negeri (PN) Jakarta \\ e-mail: qurratul-a@gmail.com
}

\begin{abstract}
Sharia Financial Institutions Receiving money Waqf (LKS-PWU) has a very important role for the optimization of money waqf. This is because the money waqf can not be submitted directly to nazhir, but must go through the Sharia Financial Institution Receiver of Money Waqf (LKS-PWU). And to support it, the Sharia Financial Institution Receiving Money Waqf should have professional management in the collection, as well as management mechanisms, and need accountability and integrity in the reporting side of the management of waqf money received.
\end{abstract}

Keywords: Cash Waqf, LKS-PWU, and Accountability

\section{Pendahuluan}

Agama islam adalah agama yang lengkap dimana tidak hanya mengajarkan ibadah saja tetapi juga muamalah. Islam telah secara sempurna menjelaskan etika bisnis seperti kejujuran, keterbukaan dan lain-lain yang pada akhirnya akan menguntungkan semua pihak. Selain etika Islam diatas, 
instrumen-instrumen keuangan syariah juga sangatlah beragam. Ada instrumen instrumen keuangan yang diperuntukkan untuk bisnis, misalnya jual beli atau dalam bahasa arabnya disebut dengan bai', contohnya bai' murabahah. Sewa menyewa yang dalam bahasa arabnya disebut dengan ijarah dan kerjasama yang dalam bahasa arabnya disebut dengan syirkah.

Selain itu, Islam juga menjelaskan tentang instrumeninstrumen keuangan untuk mengatasi masalah masalah sosial. Kemiskinan dan keterbelakangan adalah masalah yang ada dihadapan kita sekarang ini dan kita membutuhkan instrumen instrumen zakat dan wakaf. Seperti kita tahu saat ini geliat zakat dan wakaf di Indonesia berkembang dengan pesat. Kesadaran masyarakat Indonesia untuk berzakat dan berwakaf baik melalui wakaf tunai maupun wakaf bentuk lain terus meningkat. Ini patut disyukuri mengingat kedua instrument tersebut fokus pada pemenuhan kebutuhan dasar yang pada faktanya belum semua elemen masyarakat menikmatinya.

Harta benda yang diwakafkan tidak akan habis, karena sesungguhnya yang dimanfaatkan hanyalah hasilnya saja. Hal ini memberikan peluang untuk memanfaatkan wakaf sebagai salah satu cara meningkatkan kesejahteraan umat dan kesejahteraan manusia pada umumnya. Wakaf merupakan instrumen ekonomi Islam yang sudah ada semenjak awal kedatangan Islam. Sepanjang sejarah Islam, wakaf telah menunjukkan peran penting dalam mengembangkan kegiatan-kegiatan sosial, ekonomi dan kebudayaan. Selain itu, keberadaan wakaf telah banyak memfasilitasi para sarjana muslim untuk melakukan riset dan pendidikan, sehingga dapat mengurangi ketergantungan pendanaan kepada pemerintah.

Wakaf terbukti telah menjadi instrumen jaminan sosial dalam rangka membantu kaum yang lemah untuk memenuhi hajat hidup, baik berupa kesehatan, biaya hari tua, kesejahteraan hidup, dan pendidikan. Wakaf uang lebih fleksibel dan menjadi pendorong terhadap wakaf benda tidak bergerak agar lebih 
produktif. Indonesia memiliki aset wakaf tanah yang luas yang dapat dikembangkan melalui wakaf uang.

Berdasarkan data yang dihimpun Departemen Agama RI, jumlah tanah wakaf di Indonesia mencapai 2.686.536.656, 68 meter persegi atau 268.653,67 hektar yang tersebar di 366.595 lokasi di seluruh Indonesia. Dilihat dari sumber daya alam atau tanahnya (resources capital) jumlah harta wakaf di Indonesia merupakan jumlah harta wakaf terbesar di seluruh dunia. Ini merupakan tantangan bagi umat Islam Indonesia untuk memfungsikan harta wakaf secara maksimal sehingga tanah-tanah tersebut mampu menyejahterakan umat Islam di Indonesia. Sayangnya, potensi itu masih belum dimanfaatkan secara optimal, karena berbagai faktor (www.dakwatuna.com).

Terdapat beberapa faktor yang menyebabkan wakaf di Indonesia belum berperan dalam memberdayakan ekonomi umat, di antaranya: Pertama, Pemahaman masyarakat tentang hukum dan benda yang diwakafkan. Masyarakat masih berasumsi benda yang diwakafkan harus dalam bentuk benda tak bergerak, seperti tanah yang peruntukkannya untuk ibadah mahdhah dan lain sebagainya. Sedangkan uang apalagi dalam pecahan kecil, sebagian masyarakat menganggap tak bisa dikelompokkan sebagai wakaf. Pemahaman yang berkembang dalam masyarakat ini dipengaruhi oleh pemikiran madzhab Syafi'i. Tentunya referensi tentang produk fiqih ini tidak diimbangi dengan pembanding fiqih lain yang sangat dimungkinkan dalam pengembangan wakaf. Hal inilah yang menyebabkan pandangan masyarakat tentang wakaf sangat terbatas, masih bersifat konvensional dan belum mengarah ke arah yang produktif . Padahal apabila kita amati tentang wakaf uang yang potensial, ia bisa menjadi salah satu Instrumen keuangan Syariah untuk pembangunan Ekonomi di Indonesia.

Kedua, Masalah sosialisasi, salah satu madzhab yang populer di Indonesia adalah Madzhab Syafi'i. Di mana Madzhab Syafi'i tidak menerangkan tentang wakaf uang. Hal ini merupakan 
tantangan karena masyarakat akan mengalami konflik dengan adanya pemahaman yang dianggap baru di kalangannya. Tak hanya terjadi pada masyarakat, masalah sosialisasi juga terhambat pada media, baik media cetak dan elektronik. Sosialisasi dan edukasi mengenai wakaf belum terlihat masif. Hal inilah yang menyebabkan masalah wakaf uang tidak familiar di kalangan masyarakat.

Ketiga, Masalah kelembagaan yang masih belum maksimal melakukan pengumpulan wakaf uang. Dan keempat, Kurangnya kepekaan Pemerintah untuk memanfaatkan potensi wakaf uang sehingga akses masyarakat untuk menyalurkan wakafnya masih belum dijangkau secara optimal serta transparansi dalam pengelolaan dan alokasi dana wakaf masih kurang sehingga hal ini dapat menurunkan kepercayaan masyarakat untuk menyalurkan wakaf.

Inti dari wakaf adalah bahwa pokok dari aset wakafnya tidak boleh berkurang. Aset yang telah diserahkan oleh wakif atau pemberi wakaf kepada nazir atau pengelola wakaf haruslah benar benar dipelihara oleh nazir. Nazir bertanggung jawab untuk membesarkan aset tersebut. Nazir harus bertanggung jawab ketika aset tersebut berkurang. Orientasi bisnis dan sosial yang ada dalam wakaf adalah wakaf terutama wakaf tunai yang diterima oleh nazir haruslah diinvestasikan untuk mencari profitprofit sebesar besarnya untuk kemudian diberikan kepada mauquf alaih atau penerima manfaat wakaf. Tujuan mencari alternatif bisnis yang menghasilkan laba adalah agar banyak mauquf alaih yang dibantu. Dalam hal ini tentu perlu suatu jalinan kerja sama antar sesama lembaga keuangan penerima wakaf uang, namun sebagaimana kita lihat kerjasama tersebut belum nampak, dan terkesan masing-masing lembaga berjalan sendiri-sendiri.

Berdasarkan hal-hal tersebut diatas, Penulis tertarik untuk membahas tentang bagaimanakah peran lembaga keuangan syariah penerima wakaf uang (LKS-PWU) bagi optimalisasi wakaf uang. 


\section{Pembahasan}

\section{Pengertian dan dasar hukum wakaf uang}

Kata wakaf atau waqf berasal dari bahasa Arab yang berasal dari akar kata wa-qa-fa berarti menahan, berhenti, diam di tempat atau berdiri. Kata waqafa-yaqifu-waqfan semakna dengan kata habasa-yahbisu-tahbisan maknanya terhalang untuk menggunakan. Kata waqf dalam bahasa Arab mengandung makna, artinya: menahan, menahan harta untuk diwakafkan, tidak dipindahmilikkan (al-Mishri,: XI/276). Dalam bahasa Arab, istilah wakaf kadang-kadang bermakna objek atau benda yang diwakafkan (al-mauquf bih) atau dipakai dalam pengertian wakaf sebagai institusi seperti yang dipakai dalam perundangundangan Mesir. Di Indonesia, term wakaf dapat bermakna objek yang diwakafkan atau institusi (Juhaya S. Praja, 1995: 6).

Menurut istilah meskipun terdapat perbedaan penafsiran, disepakati bahwa makna wakaf adalah menahan dzatnya benda dan memanfaatkan hasilnya atau menahan dzatnya dan menyedekahkan manfaatnya (Abu Zahrah,: 41) Dalam bahasa Indonesia kata waqaf biasa diucapkan dengan wakaf dan ucapan inilah yang dipakai dalam perundang-undangan di Indonesia. Sedangkan menurut istilah wakaf menghentikan atau menahan perpindahan milik suatu harta yang bermanfaat dan tahan lama sehingga manfaat harta tersebut dapat digunakan untuk mencari keridhaan Allah SWT. (Departemen Agama, 207)

Dalam Kompilasi Hukum Indonesia (KHI) disebutkan bahwa: "Wakaf adalah perbuatan hukum seseorang atau kelompok orang atau badan hukum yang memisahkan sebagian dari harta miliknya dan melembagakannya untuk selamalamanya guna kepentingan ibadah atau keperluan umum lainnya sesuai dengan ajaran islam." (Dadan Muttaqien dkk, 1999: 298)

Definisi wakaf menurut Undang-undang No. 41 tahun 2004, tentang Ketentuan umum menyatakan bahwa: «Wakafadalah perbuatan hukum wakif untuk memisahkan dan/atau menyerahkan 
sebagian harta benda miliknya untuk dimanfaatkan selamanya atau untuk jangka waktu tertentu sesuai dengan kepentingannya guna keperluan ibadah dan/atau kesejahteraan umum menurut syari>ah» (UU RI No. 41 Tahun 2004 Tentang Wakaf)

Definisi ini tergolong definisi yang cukup longgar dan mengakomodasi perbedaan pendapat dikalangan ahli fiqh dan mempertimbangkan pengembangan objek wakaf demi kemaslahatan umat. Beberapa catatan yang dapat dikemukakan adalah: (1) fleksibilitas bentuk objek wakaf dalam Inpres sebenarnya sudah mengakomodir semua pandangan ahli fiqh, tetapi tertutupi oleh pandangan hierarkhi terhadap pandangan hukum di Indonesia, bahwa Peraturan Pemerintah (PP) lebih tinggi dari pada Intruksi Presiden (Inpress), sehingga dengan lahirnya UU tersebut fleksibilitas tersebut lebih kuat payung hukumnya; (2) Kendala fanatisme madzhab yang kuat di akar rumput dalam meyakini objek wakaf adalah tanah (yang ia termasuk barang tak bergerak), sehingga implementasi belum berjalan mulus; (3) Durasi waktu dimunculkan mengakomodasi madzhab Maliki yang menafsirkan adanya wakaf temporal; (4) kata "keperluan umum" dirubah "kesejahteraan umum" mencerminkan sasaran final wakaf adalah masyarakat dapat menikmati wakaf sebagai salah satu media yang bisa mensejahterakannya; (5) kata "Agama Islam" atau "Islam" dirubah menjadi "Syariah".

Undang-undang Nomor 41 tahun 2004 telah memperluas benda yang dapat diwakafkan oleh wakif, yang dulu sebelum adanya undang-undang ini secara umum hanya terbatas pada benda tidak bergerak atau benda tetap seperti tanah dan bangunan, kini dalam undang-undang tersebut juga diatur mengenai wakaf benda bergerak seperti wakaf tunai (uang). Wakaf Uang dalam Peraturan Menteri Agama No. 4/ 2009 adalah perbuatan hukum Wakif untuk memisahkan dan/atau menyerahkan sebagian uang miliknya untuk dimanfaatkan selamanya atau untuk jangka waktu tertentu sesuai dengan kepentingannya guna keperluan ibadah dan/atau kesejahteraan umum menurut Syariah. 
Adapun Wakaf tunai dalam Undang-undang nomor 41 tahun 2004 diatur dalam Pasal 28 sampai Pasal 31, yakni:

Pasal 28: Wakif dapat mewakafkan benda bergerak berupa uang melalui lembaga keuangan syariah yang ditunjuk oleh menteri.

Pasal 29: 1) Wakaf benda bergerak berupa uang sebagaimana pasal 28 dilaksanakan oleh wakif dengan pernyataan kehendak Wakif dilakukan secara tertulis; 2) Wakaf benda bergerak berupa uang sebagaimana dimaksud dalam pasal 1 diterbitkan dalam bentuk sertifikat wakaf uang; 3) Setrtifikat wakaf uang sebagaimana dimaksud dalam pada ayat 2 diterbitkan dan disampaikan oleh lembaga keuangan syariah kepada Wakif dan Nazhir sebagai bukti penyerahan harta benda wakaf.

Pasal 30: Lembaga keuangan Syariah atas nama nazhir mendaftarkan harta benda wakaf berupa uang kepada menteri selambatlambatnya 7 (tujuh) hari sejak diterbitkannya sertifikat wakaf uang.

Pasal 31: Ketentuan lebih lanjut mengenai wakaf benda bergerak berupa uang sebagaimana dimaksud pasal 28, 29, dan 30 diatur dalam peraturan pemerintah.

Mengenai masalah Wakaf Tunai, MUI telah membolehkan Wakaf tunai, ini dibuktikan dengan adanya fatwa MUI Indonesia tanggal 11 Mei 2002 yang berbunyi:

1) Wakaf uang (cash wakaf/ waqf al-nuqud) adalah wakaf yang dilakukan seseorang, kelompok orang, lembaga atau badan hukum dalam bentuk uang tunai.

2) Termasuk ke dalam pengertian uang adalah surat-surat berharga.

3) Waqaf uang hukumnya jawaz (boleh).

4) Wakaf uang hanya boleh disalurkan dan digunakan untuk hal-hal yang dibolehkan secara syar'i. Nilai pokok wakaf uang harus dijamin kelestariannya, tidak boleh dijual, dihibahkan dan atau diwariskan.

\section{Peran LKS-PWU dalam mengoptimalkan wakaf uang}

Sejarah Lembaga Keuangan Syariah di Indonesia tidak lepas dari undang-undang yang pernah dibuat oleh pemerintah 
No.7 Tahun 1992. Undang-undang ini dianggap sebagai payung hukum bagi lahirnya lembaga keuangan syariah. Undang-undang ini menyebutkan kemungkinan berdirinya sebuah bank dengan sistem bagi hasil. UU ini kemudian menjadi dasar lahirnya Bank Muamalat Indonesia. Undang-undang ini kemudian disempurnakan dengan Undang-Undang No.10 Tahun 1998 tentang Perbankan yang memungkinkan beroperasinya dual banking system dalam sistem perbankan nasional. Akibatnya, sejumlah bank konvensional di Indonesia membuka divisi syariah dalam sistem pelayanan mereka kepada para nasabah (Mustafa Edwin Nasution, 2007: 291).

Pada tahun 2005 telah berdiri 3 Bank Umum Syariah (BUS) seperti: Bank Muamalat Indonesia (BMI), Bank Syariah Mandiri (BSM), dan Bank Syariah Mega Indonesia (BSMI). Selain itu sedikitnya terdapat 19 Unit Usaha Syariah (UUS) seperti: IFI, Bukopin, Danamon, Niaga, BNI, BRI, BII, HSBC, BTN, Bank DKI, Bank Jabar, BPD Sumut, BPD Riau, BPD Kalsel, BPD Aceh, BPD NTB, BPD Kalbar, dan BPD Sumsel. Selain Unit Usaha Syariah ini, telah beroperasi 92 BPR Syariah. Seiring dengan bertambahnya jumlah bank yang menyediakan layanan syariah, bank-bank ini juga membuka jaringan kantornya di beberapa wilayah di Indonesia. Penyebarana jaringan perkantoran di beberapa wilayah ini tentu saja mengikuti tingkat aktifitas bisnis yang berada di wilayah-wilayah tersebut.

Dewasa ini kantor-kantor bank syariah ini sudah menyebar di hampir seluruh pelosok tanah air. Sekalipun pada tahun 2007 jumlah BUS masih sama dengan tahun 2005 tetapi jumlah Unit Usaha Syariah meningkat menjadi 23 UUS dan 532 kantor cabang (termasuk Kantor Cabang Pembantu (KCP), Unit Pelayanan Syariah (UPS), dan Kantor Kas (KK) dan 106 BPR Syariah.

Aset perbankan syariah per Mei 2007 lebih dari Rp. 29 triliun dengan jumlah Dana Pihak Ketiga mencapai Rp. 22,5 triliun. Sekalipun jumlah aset perbankan syariah baru berkisar 1,63\% dan dana pihak ketiga yang terhimpun baru mencapai 1,69\% dari 
total aset perbankan nasional (per 2007), namun diprediksikan pertumbuhan dan perkembangannya sangat menjanjikan di masa yang akan datang. (Syafi'i Antonia dan S. Rusydiana, 2010: 46-57) Tiga tahun berikutnya, menurut data statistik yang dirilis Bank Indonesia, pada akhir tahun 2010, jumlah bank umum syariah (BUS) yang beroperasi di Indonesia telah mencapai 11 bank dan 23 unit usaha syariah serta 150 Bank Pembiayaan Rakyat Syariah (BPRS). (Bambang Rianto Rustam, 26 Maret 2011).

Sampai dengan 31 Desember 2015, Menteri Agama sudah menetapkan 15 bank sebagai penerima setoran wakaf uang, yang disebut LKS-PWU. Bank-bank itu adalah sebagai berikut: Bank Muamalat Indonesia, Bank Syariah Mandiri, Bank BNI Syariah, Bank Mega Syariah, Bank DKI Syariah, Bank BTN Syariah, Bank Syariah Bukopin, BPD Jogya Syariah, BPD Kalbar Syariah, BPD Jateng Syariah, BPD Kepri Riau Syariah, BPD Jatim Syariah, BPD Sumut Syariah, Bank CIMB Niaga Syariah, Panin Bank Syariah

Profesionalisme lembaga pengelolaan wakaf terhadap harta wakaf dan pemanfaatannya merupakan media penyadaran bagi masyarakat akan pentingnya wakaf produktif dalam hal ini wakaf uang. Efektifitas pengelolaan mutlak di lakukan oleh lembaga pengelolaan wakaf. Menurut MA Mannan, salah satu indikator efektifitas wakaf Produktif adalah income redistribution (redistribusi pendapatan). Pengeluaran dana-dana yang diperoleh dari hasil pengelolaan wakaf berperan penting pada setiap redistribusi pendapatan secara vertikal. Pengeluaran danadana wakaf harus dikoordinasikan sehingga efek redistribusi pendapatan dapat berpihak pada golongan miskin, yakni dengan penyediaan jasa dan prasarana penting bagi orang miskin, seperti sarana pendidikan (Mannan, 2008: 8).

Oleh karena itu, lembaga pengelola wakaf produktif seyogyanya memenuhi kriteria sebagai berikut :

1. Memiliki akses yang baik kepada calon wakif.

2. Memiliki kemampuan untuk menginvestasikan dana wakaf. 
3. Mampu untuk mendistribusikan hasil/keuntungan dari investasi dana wakaf.

4. Memiliki kemampuan untuk mencatat segala hal yang berkaitan dengan beneficiary, misalnya rekening dan peruntukannya.

5. Lembaga pengelola wakaf tunai hendaknya dipercaya oleh masyarakat dan kinerjanya dikontrol sesuai dengan peraturan perundang-undangan yang berlaku terhadap lembaga pengelola dana publik.

Guna meningkatkan profesionalisme, kerangka manajemen efektif perlu dilakukan. Adapun tahapan manajerial lembaga pengelolaan wakaf dapat dilakukan sebagai berikut:

1. Perencanaan, yaitu proses yang menyangkut upaya yang dilakukan untuk mengantisipasi kecenderungan dimasa yang akan akan datang dan penentuan strategi dan taktik yang tepat untuk mewujudkan target dan tujuan wakaf. Dalam perencaan pengembangan harta wakaf, perencanaan ini berguna sebagai pengarah meminimalisasi ketidakpastian, meminimalisasi pemborosan sumber daya dan sebagai penetapan standar dalam kualitas pengawasan.

2. Pengorganisasian, yaitu proses yang menyangkut bagaimana strategi dan taktik yang telah dirumuskan dalam prencanaan didesain dalam struktur organisasi yang tepat dan tangguh, sistem dan lingkungan organisasi yang kondusif dan memastikan bahwa semua nazhir bisa bekerja secara efektif dan efisien guna mencapai tujuan wakaf.

3. Pengimplementasian, yaitu proses implementasi program agar bisa dijalankan oleh seluruh pihak (para nazhir) dalam organsisasi serta proses memotivasi agar semuanya dapat menjalankan tanggung jawab dengan penuh kesadaran dan produktifitas yang tinggi. 
4. Pengendalian dan pengawasan, yaitu proses yang dilakukan untuk memastikan seluruh rangkaian kegiatan yang telah direncanakan, diorganisasikan dan diimplementasikan bisa berjalan sesuai dengan target yang diharapkan sekalipun berbagai perubahan terjadi.

Berkaitan dengan mekanisme pengelolaan dan pelaporan keuangan pada lembaga wakaf, agar meraih kepercayaan dari masyarakat, lembaga wakaf perlu melaksanakan transparansi dan akuntabilitas. Transparansi berarti adanya keterbukaan dalam melaksanakan tugas-tugas. Setiap aktivitas selalu dibuktikan dengan data yang kuat, sah dan akurat. Sedangkan akuntabilitas merupakan rasa tanggung jawab yang menuntut pelaksanaan tugas yang telah diamanahkan. Untuk itu dalam mengelola dana wakaf, nazhir wakaf tentu harus membuat laporan keuangan secara regular yang dapat diakses dengan mudah oleh wakif. nazhir dapat mengelola dana wakaf secara produktif sehingga dapat memberdayakan ekonomi masyarakat miskin. Dan integritas nazhir merupakan persoalan yang penting, dalam mengelola dana wakaf nazhir harus menghindari bentuk $\square$ bentuk bisnis yang akan merendahkan kredibilitasnya, semua perencanaan aktivitas bisnis ayang akan disusun harus sesuai dengan hukum Islam. Peningkatan dana wakaf agar lebih produktif dan signifikan dalam upaya pemberdayaan dan peningkatan kesejahteraan ekonomi umat, antara lain dapat dilakukan dengan cara sosialisasi, edukasi dan informasi.

Peran LKS sangat strategis terutama dalam pengembangan wakaf uang di Indonesia. Peran strategis ini salah satunya terkait dengan status hukum lembaga ini karena ditunjuk langsung oleh Menteri Agama sebagai lembaga berwenang dalam penerimaan wakaf uang. Hal ini disebutkan dalam UU No. 41 tahun 2004 Pasal 28 tentang wakaf yang berbunyi: 'Wakif dapat mewakafkan benda bergerak berupa uang melalui lembaga keuangan syariah yang ditunjuk oleh menteri'. Dalam kaitan ini menteri memiliki wewenang untuk menunjuk lembaga keuangan syariah tertentu 
yang memenuhi persyaratan atas saran dan pertimbangan dari Badan Wakaf Indonesia (Pasal 24 ayat 1 Penjelasan).

Sekalipun menteri berwenang menunjuk lembaga keuangan syariah sebagai penerima wakaf, tidak semua LKS dapat menjadi penerima wakaf uang umat Islam. Undang-undang No. 41 tahun 2004 memberikan syarat-syarat tertentu bagi LKS yang dapat menerima dana wakaf uang masyarakat. Persyaratanpersyaratan ini meliputi: (a). LKS harus menyampaikan permohonan secara tertulis kepada Menteri, (b). melampirkan anggaran dasar dan pengesahan sebagai badah hukum, (c). memiliki kantor operasional di wilayah Republik Indonesia, (d). bergerak di bidang keuangan syariah dan (e). memiliki fungsi titipan (wadi'ah). Persyaratan yang ketat ini dimaksudkan agar dana wakaf uang yang terkumpul di lembaga keuangan syariah ini dapat dijamin kelestarian dan keamanannya.

Selain status hukum yang kuat, peran strategis LKS dalam pengembangan wakaf uang di Indonesia terutama berkaitan dengan jejaring yang dimiliki oleh lembaga ini. Sebagian besar Lembaga Keuangan Syariah memiliki jaringan kantor cabang serta fasilitas ATM yang banyaki, SMS banking, Internet Banking, Phone Banking, dan fasilitas auto debet. Luasnya jaringan dan fasilitas bank ini pada gilirannya memudahkan umat Islam di seluruh pelosok Indonesia untuk dapat berpartisipasi dalam menunaikan ibadah wakaf uang.

Disamping jaringan yang luas, LKS di Indonesia juga memiliki sumber daya manusia handal yang dapat menunjang tecapainya pengumpulan dana wakaf umat secara optimal. Selain itu, dana-dana yang terkumpul dalam lembaga keuangan syariah ini umumnya di bawah jaminan Lembaga Penjamin Simpanan sehingga dana wakaf uang yang terkumpul dapat terjamin keamanannya (Mulya E. Siregar, 2011: 49-59). Peran strategis ini menumbuhkan optimisme baru betapa LKS -PWU dapat menopang gerakan wakaf uang produktif di Indonesia. 


\section{Simpulan}

Berdasarkan uraian diatas, maka Penulis dapat menyimpulkan bahwa Lembaga Keuangan Syariah Penerima Wakaf Uang (LKS-PWU) memiliki peranan yang sangat penting bagi optimalisasi wakaf uang. Hal ini dikarenakan wakaf uang tidak dapat diserahkan secara langsung kepada nadzhir, melainkan harus melalui Lembaga Keuangan Syariah Penerima Wakaf Uang (LKS-PWU). Dan untuk menunjang hal tersebut, maka Lembaga Keuangan Syariah Penerima Wakaf Uang haruslah memiliki manajemen yang profesional dalam pengumpulan, serta mekanisme pengelolaannya, serta perlu akuntabilitas dan integritas dalam sisi pelaporan atas pengelolaan wakaf uang yang diterima.

\section{Daftar Pustaka}

Abdul Ghafur Anshori, Hukum dan Praktik Perwakafan di Indonesia, Pilar Media, Yogyakarta, 2005.

Abu Sūud Muhammad. Risalah fi Jawazi Waqf al-Nuqud, Dar Ibn Hazm, Beirut, 1997.

Abu Zahrah. Muhadharat fi al-Waqf, Dar al-Fikr al-'Arabi, Beirut, 1971.

Ahmad Azhar Basyir, Hukum Islam Tentang Wakaf, Ijarah, Syirkah, PT. Maarif, Bandung, 1987.

Andri Soemitra, Bank dan Lembaga Keuangna Syariah, Prenada Media, Medan, 2009.

Asri Sitompul. Reksa dana: Pengantar dan Pengenalan Umum, Citra Aditya Bakti, Bandung, 2003.

Burhanuddin Susanto, Pasar Modal Syariah (Tinjauan Hukum), UII Press, Yogyakarta, 2008.

Dadan Muttaqien dkk., Peradilan Agama dan Kompilasi Hukum Indonesia, UII Press, Yogyakarta, 1999. 
Heri Sudarsono. Bank dan Lembaga Keuangan Syariah Deskripsi Dan Ilustrasi. Ekonisia, Yogyakarta, 2004.

Imam Suhadi, Hukum Wakaf di Indonesia, Dua Dimensi, Yogyakarta, 1985.

Juhaya S. Praja, Perwakafan di Indonesia: Sejarah, Pemikiran, Hukum dan Perkembangannya, Yayasan Piara, Bandung, 1995.

Laporan Penerimaan Wakaf Uang Badan Wakaf Indonesia September 2010.

M. Dawam Rahardjo, Menegakkan Syariat Islam di Bidang Ekonomi, dalam Adiwarman Azwar Karim. Bank Islam: Analisis Fiqih dan Keuangan, Rajawali Press, Jakarta, 2004.

M.A. Mannan. Sertifikat Wakaf Tunai, CiBER bekerjasama dengan PKTTIUI, Jakarta, 2005.

Mulya E. Siregar, Peranan Perbankan Syariah dalam Implementasi Wakaf Uang", dalam Al-Awaqaf, Volume IV, Nomor 04, Januari 2011.

Mustofa Edwin Nasution et.al., Pengenalan Eksklusif Ekonomi Islam, Kencana Prenada Media Group, Maret 2007.

Syafi'i Antonia dan S.Rusydiana, Peranan Ekonomi Syaria'h dalam Pembangunan Daerah, dalam Harmoni, Vol. IX, No. 33, Januari-Maret 2010.

Undang-Undang No 41 Tahun 2004 Tentang Wakaf 